\title{
Perbandingan Manfaat Vaksin Oral Polio 1 [Monovalen] dengan Vaksin Oral Polio Trivalen Terhadap Transmisi Virus Polio 1 dalam Upaya Mengatasi Kejadian Luar Biasa Polio 1 di Indonesia Tahun 2005: ditinjau melalui respons imun dan keamanannya
}

\section{Kusnandi Rusmil}

Bagian Ilmu Kesehatan Anak FK Universitas Padjadjaran/RS Hasan Sadikin, Bandung

\begin{abstract}
Latar belakang. Indonesia menggunakan trivalent oral polio vaccine (tOPV) sejak tahun 1977 dan sejak tahun 1995 tidak pernah ditemukan lagi kasus poliomelitis. Pada Maret 2005 terjadi kejadian luar biasa (KLB) polio yang meluas ke seluruh pulau Jawa dan Sumatera. Berdasarkan pengalaman negara yang berhasil mengatasi KLB, penggunaan monovalent oral polio vaccine (mOPV) sesuai penyebab KLB memberikan hasil lebih cepat dibandingkan tOPV.

Tujuan. Melihat manfaat pemberian mOPV1 dibandingkan dengan tOPV ditinjau dari imunogenisitas dan keamanan vaksin.

Metode. Penelitian dilakukan pada anak berumur 0-12 bulan, menggunakan mOPV1 dan tOPV saat saat Pekan Imunisasi Nasional tahun 2005.

Hasil. Penelitian menunjukkan sero konversi pada kelompok mOPV terdapat pada 19 subjek dan tOPV pada 2 subjek, dengan titer rerata masing-masing 69,47 dan 48. Proporsi kenaikan titer $\geq 4$ kali kelompok mOPV1 40,5\%, tOPV 27,2\% ( $\left.X^{2}=5,49 ; p=0,014\right)$. GMT kelompok mOPV1 21,9 menjadi 54,84 ( $\mathrm{Ww}=5,45$; $p<0,001)$; kelompok tOPV 42,93 menjadi 52,30 ( $\mathrm{Zw}=1,488 ; p=0,137)$. Ekskresi virus polio 1 pada hari ke-7 dan ke-21 setelah pemberian mOPV1 berturut-turut 38\%, dan $4 \%(p<0,001)$, pada kelompok tOPV berturut-turut $26 \%$, dan $14 \%\left(X^{2}=1,65 ; p=0,125\right)$.

Kesimpulan. Respon imun mOPV1 memberikan respons yang lebih baik dibandingkan dengan tOPV dan kedua kelompok vaksin mempunyai keamanan yang sama, tidak ditemukan reaksi KIPI yang berat selama penelitian. (Sari Pediatri 2009;11(1):71-8).
\end{abstract}

Kata kunci: monovalent oral polio vaccine (mOPV1), trivalent oral polio vaccine (tOPV), KLB, PIN

Alamat korespondensi

DR. Kusnandi Rusmil, dr., Sp.A(K). Bagian/UPF Ilmu Kesehatan Anak FKUP/RSUP

dr. Hasan Sadikin Jl. Pasteur No. 38 Telp./Fax. 2034426-203595 Bandung 40161

Sari Pediatri, Vol. 11, No. 1, Juni 2009 
Kusnandi Rusmil: Perbandingan Vaksin Oral Polio 1 Monovalen dengan Trivalen Upaya Mengatasi KLB Polio Di Indonesia

$\mathrm{P}$ ada tahun 2005 tiga negara yang telah bebas polio selama beberapa tahun, mengalami kejadian luar biasa (KLB) penyakit polio, dimulai dari Yaman, Sudan, dan Indonesia. Di Indonesia kasus pertama KLB ditemukan di Sukabumi, kemudian menyebar ke provinsi lain. Terjadinya ledakan KLB kasus polio karena adanya importasi virus polio dari negara yang masih endemis seperti India, Afghanistan, Pakistan, dan Nigeria. Pelacakan genetik menunjukkan bahwa galur polio di Indonesia berasal dari Afrika Barat (Nigeria). Adanya penularan penyakit Polio menggambarkan banyaknya kelompok anak atau orang dewasa yang belum mempunyai kekebalan terhadap virus polio pada mukosa ususnya, sehingga anak atau orang dewasa tersebut menularkan virus dari orang ke orang sekitarnya melalui route fecal-oral atau oral-oral. ${ }^{1}$

Trivalent tOPV merupakan vaksin yang selama ini telah digunakan untuk program imunisasi secara rutin dan program imunisasi tambahan di negara kita dan telah terbukti cukup efektif dan aman. ${ }^{2}$ Setelah mendapat vaksin oral polio vaccine (OPV), maka virus polio vaksin akan merangsang pembentukan SIgA (secretory Immunoglobulin A) di dinding dan lumen usus. Adanya SIgA secretory akan memberi kekebalan di mukosa usus yang berlangsung kurang lebih selama 100 hari dan dapat bertahan sampai dua tahun atau lebih lama. Sehingga anak yang mendapat OPV tidak terjadi replikasi virus polio dalam usus walaupun tubuhnya belum kebal secara sistemik. ${ }^{2,3-5}$ Oleh karena itulah pada kejadian KLB polio, WHO merekomendasikan dan mengharuskan untuk menggunakan OPV. ${ }^{3}$ Memperhatikan kejadian KLB di Jawa Barat setelah dilakukan tindakan out break respon imun dan mopping up dengan trivalent oral polio vaccine (tOPV) meskipun jumlah kasus polio tampak menurun di Jawa Barat tapi untuk daerah-daerah di luar provinsi penularan virus polio semakin bertambah. Tercatat 305 kasus polio tersebar di seluruh Jawa dan Sumatera. Untuk mengatasi penyebaran/transmisi virus polio 1 dengan cepat, harus ada upaya lain untuk memutus mata rantai penularan virus polio, ${ }^{1}$ oleh sebab itu pada PIN putaran ke-5 bulan November 2005, mengacu kepada pengalaman negara Amerika, Yaman, dan India, di daerah tempat terjadinya kasus penularan virus polio liar akan diberikan vaksin polio tunggal (mOPV) sesuai dengan jenis virus polio yang ditemukan, sedangkan di daerah tanpa kasus transmisi virus polio liar tetap diberikan vaksin polio trivalen
(tOPV). Mengingat penyebab KLB polio di Indonesia adalah virus polio 1 maka pemberian satu galur virus vaksin polio $1 \mathrm{mOPV}$ saja akan lebih imunogenik dibandingkan pemberian tiga galur virus vaksin tOPV.1 Tujuan penelitan untuk menilai imunogenisitas dan keamanan mOPV1 dan tOPV pada saat PIN bulan November 2005 di Indonesia.

\section{Metode}

Tempat penelitian daerah KLB di Bandung pada Puskesmas Garuda, Puskesmas Padasuka, dan Puskesmas Puter. Sedangkan di daerah bukan KLB polio, di Puskesmas Banjarbaru, Puskesmas Sei Besar dan Puskesmas Cempaka, Banjarmasin di Kalimantan Selatan subjek dipilih berdasarkan purposis sampling. ${ }^{6,7}$ Penelitian dilakukan pada bulan November 2005 sampai dengan Januari 2006.

Tujuan khusus penelitian untuk mengukur serokonversi setelah pemberian tOPV dan mOPV1, peningkatan titer antibodi polio 1 setelah pemberian tOPV dan mOPV1, ekskresi virus polio dari feses setelah pemberian tOPV dan mOPV1, dan membandingkan keamanan mOPV1 dengan tOPV pada saat PIN ke-5.

Penelitian eksperimental ${ }^{6,7}$ dengan melakukan intervensi pada komunitas dengan pemberian imunisasi $t O P V$ dan $m O P V 1$ pada saat Pekan Imunisasi Nasional (PIN) KLB polio 2005. Kelompok 1 adalah sejumlah subjek yang berlokasi di daerah KLB polio, dan kelompok 2 adalah sejumlah subjek yang berlokasi di daerah bukan KLB. Dari masing-masing kelompok, dikaji dan dibandingkan mengenai imunogenisitas vaksin dengan mengukur titer antibodi anti polio pra dan 30 hari pasca pemberian $t O P V$ dan $m O P V 1$. Pada hari ke-7 dan ke-21 setelah pemberian imunisasi pada kedua kelompok dilakukan pemeriksaan virus yang diekskresi dalam feses untuk menilai kekebalan mukosa usus. Virus dideteksi melalui isolasi atau biakan, dilakukan di laboratorium Bio Farma Bandung. Di samping itu dilakukan pula kajian keamanan kedua vaksin tersebut.

Populasi terjangkau yang diteliti adalah anak sehat peserta PIN yang berumur kurang dari 12 bulan yang berada di sekitar Puskesmas yang telah ditentukan dan memenuhi kriteria inklusi. Kriteria inklusi adalah anak sehat menurut dokter pemeriksa, dan orangtua bersedia menandatangani surat persetujuan, serta siap mematuhi aturan dan jadwal penelitian. Kriteria eksklusi 
adalah anak yang mengalami sakit terutama penyakit infeksi atau demam (temperatur aksila $\geq 37,5^{\circ} \mathrm{C}$ ), atau menderita penyakit berat lainnya tidak diikutsertakan dalam penelitian. Pada empat minggu sebelum penelitian telah menerima pengobatan yang kemungkinan akan mengubah respon imun misalnya terapi sistemik kortikosteroid jangka-panjang ( $>2$ minggu), imunoglobulin, produk darah intra vena, dan telah diimunisasi polio di luar penelitian dalam masa penelitian, tidak diikutkan.

Cara penghitungan besar sampel dengan asumsi superioritas yaitu terjadinya peningkatan antibodi polio $1>20 \%$ pada hari ke-30 setelah pemberian $m O P V 1$ dibandingkan respon antibodi polio 1 setelah pemberian $t O P V{ }^{8,9}$ Power test 1 : $\beta$ 90\% (beta) dengan kemaknaan $\alpha$ 5\% (alpha), Maka diperoleh besar sampel 125 subjek. Jumlah subjek ditambah $20 \%$ untuk antisipasi drop-out, maka diperlukan total subjek 150 untuk setiap kelompok. Dengan perkiraan peluang ekskresi polio virus sesudah vaksinasi pada hari ke-7 adalah $80 \%-92 \%,{ }^{8,9}$ perhitungan besar sampel digunakan rumus untuk menaksir proporsi populasi. Dengan menetapkan taraf kepercayaan (1- $\alpha) 95 \%$ dan p $80 \%$ serta presisi $10 \%$, diperoleh besar sampel untuk pengumpulan spesimen feses 44 subjek, untuk masingmasing kelompok. Dengan penambahan 10\%, maka besar sampel per kelompok adalah 50 dari 150 yang dipilih secara random.

Prosedur pemeriksaan sampel darah dan feses, tiga mililiter darah, dan delapan gram spesimen feses dimasukkan ke dalam pot feses, dikumpulkan dan dalam waktu 24 jam dikirim ke Laboratorium Polio Bio Farma Bandung. ${ }^{10}$ Titer antibodi anti polio diukur pra imunisasi dan 30 hari pasca imunisasi berdasarkan reaksi uji neutralisasi. Subjek dengan kadar $<4$ dianggap tidak protektif. ${ }^{10}$ Dievaluasi transisi dari seronegatif ke seropositif dan yang telah mempunyai antibodi yang terdeteksi, serokonversi ditetapkan sebagai peningkatan 4 kali lipat dari kadar sebelum imunisasi serta geometric mean titer (GMT) pra dan pasca imunisasi. Pengukuran imunitas mukosa dilakukan dengan melihat adanya ekskresi virus polio pada pada hari ke-7 dan hari ke-21 sesudah imunisasi. ${ }^{8,9}$

Data keamanan vaksin dinilai dari KIPI (kejadian ikutan pasca imunisasi) yang terjadi. Yang dimaksud dengan KIPI adalah setiap kejadian yang tidak diinginkan atau merugikan pada subjek setelah imunisasi yang dilaporkan oleh orangtuanya. ${ }^{11}$ Gejala KIPI yang dinilai adalah temperatur aksila $\geq 37,5^{\circ} \mathrm{C}$ ), iritabilitas, acute flaccid parálisis, atau keluhan lain; dinilai, dalam 30 menit, 24 jam, 48 jam, 72 jam, dan 30 hari.

Data diolah dan dianalisis dengan perangkat lunak statistik Statistic ver. 4.0. Perhitungan dan uji statistik untuk mengetahui perbedaan kedua kelompok subjek digunakan uji chi-kuadrat dan uji Mann-Whitney. ${ }^{6}$ Keamanan dihitung persentase jumlah anak yang mengalami reaksi lokal dan sistemik pasca imunisasi yang terjadi dalam 30 menit, 24 jam, 48 jam, 72 jam sampai 30 hari.

\section{Hasil}

Diantara subjek penelitian yang memenuhi kriteria inklusi 299 orang bayi dapat dianalisis.

\section{- Karakteristik subjek tOPV dan mOPV1}

Kelompok tOPV terdapat pada 151 subjek yang dapat dianalisis dan kelompok mOPV1 148 subjek (Tabel 1).

- Titer antibodi antipolio

Pada pra imunisasi tOPV terdapat 2 orang subjek dengan kadar $<4$ (di bawah protektif) ${ }^{19}$ pasca imunisasi menjadi 1 orang subjek. Pra-imunisasi mOPV1 persentase anak dengan antibodi antipolio 1 dengan kadar $<4$ sebanyak $12,8 \%$ (19 subjek) pasca-imunisasi menjadi 4 orang $(2,7 \%)$ (Tabel 2$)$.

- Serokonversi setelah pemberian tOPV dan mOPV1

Pasca imunisasi 1 dosis tOPV terjadi serokonversi, maksimal terjadi pada antibodi antipolio 1 diikuti antibodi antipolio 2 dan kemudian antibodi antipolio 3 , masing-masing $(100,0 \%, 66,7 \%$, dan $57,1 \%)$. (Tabel 3). Pada pra imunisasi dari 19 subjek (12,7\%) dengan seronegatif setelah 30 hari pasca imunisasi dengan satu dosis mOPV1 semua subjek menjadi seropositif (seroconvertion rate 100\%).

- Serokonversi, proporsi, dan GMT antibodi antipolio-1 (Tabel 4)

Jumlah subjek yang mengalami peningkatan titer $\geq 4$ kali pada kelompok tOPV 27,2\% sedangkan kelompok mOPV1 40,5\%, perbedaan ini bermakna 
Tabel 1. Karakteristik subjek

\begin{tabular}{lccc}
\hline Karakteristik subjek & $\mathrm{tOPV}(\mathrm{n}=151)$ & $\mathrm{mOPV} 1(\mathrm{n}=148)$ & \multirow{2}{*}{ Kemaknaan } \\
\cline { 2 - 3 } Jenis kelamin & $\mathrm{n}(\%)$ & $\mathrm{n}(\%)$ & \\
Laki-laki & $74(49,0)$ & $75(50,7)$ & $p=0,773$ \\
Perempuan & $77(51,0)$ & $73(49,3)$ & \\
Umur (bulan) & & & \\
$\quad 0-2$ & $14(9,3)$ & $40(27,0)$ & \multirow{2}{*}{$p<0,001$} \\
$\quad 3-5$ & $71(47,0)$ & $58(39,2)$ & \\
$>6$ & $66(43,7)$ & $50(33,8)$ & \\
Rerata (bulan) $\pm(\mathrm{SD})$ & $6,1( \pm 2,6)$ & $5,2(3,2)$ & \\
Rentang & $1-11$ & $0-11$ & \\
\hline
\end{tabular}

Rerata usia pada kelompok tOPV (6.1 \pm 2.6$)$ sedangkan pada kelompok mOPV $(5.2 \pm 3.2)$ dengan perbandingan laki laki dan perempuan yang seimbang.

Tabel 2. Titer antibodi antipolio

\begin{tabular}{|c|c|c|c|c|c|c|c|c|}
\hline \multirow[t]{3}{*}{ Antibodi antipolio 1} & \multicolumn{4}{|c|}{ tOPV } & \multicolumn{4}{|c|}{ mOPV1 } \\
\hline & \multicolumn{2}{|c|}{ Pra } & \multicolumn{2}{|c|}{ Pasca } & \multicolumn{2}{|c|}{ Pra } & \multicolumn{2}{|c|}{ Pasca } \\
\hline & $\mathrm{n}$ & $\%$ & $\mathrm{n}$ & $\%$ & $\mathrm{n}$ & $\%$ & $\mathrm{n}$ & $\%$ \\
\hline$<4$ & 2 & 1,3 & 1 & 0,7 & 19 & 12,8 & 4 & 2,7 \\
\hline 4 & 6 & 4,0 & 7 & 4,6 & 13 & 8,8 & 3 & 2,0 \\
\hline 8 & 11 & 7,3 & 10 & 6,6 & 16 & 10,8 & 11 & 7,4 \\
\hline 16 & 23 & 15,2 & 25 & 16,6 & 25 & 16,9 & 16 & 10,8 \\
\hline 32 & 30 & 19,9 & 24 & 15,9 & 17 & 11,5 & 27 & 18,2 \\
\hline 64 & 35 & 23,2 & 33 & 21,9 & 29 & 19,6 & 33 & 22,3 \\
\hline 128 & 36 & 23,8 & 26 & 17,2 & 19 & 12,8 & 30 & 20,3 \\
\hline 256 & 3 & 2,0 & 10 & 6,6 & 6 & 4,0 & 15 & 10,1 \\
\hline 512 & 5 & 3,3 & 13 & 8,6 & 3 & 2,0 & 5 & 3,4 \\
\hline 1024 & 0 & 0,0 & 2 & 1,3 & 1 & 0,7 & 4 & 2,7 \\
\hline Total & 151 & 100,0 & 151 & 100,0 & 48 & 100 & 148 & 100 \\
\hline
\end{tabular}

Tabel 3. Respons antibodi

\begin{tabular}{|c|c|c|c|c|}
\hline \multirow[b]{2}{*}{ Serotipe antibodi } & \multicolumn{2}{|c|}{ Jumlah subjek } & \multirow[b]{2}{*}{$\begin{array}{c}\text { Serokonversi } \\
(\%)\end{array}$} & \multirow[b]{2}{*}{ Titer antibodi (rerata) } \\
\hline & Pra $<4$ & Pasca $\geq 4$ & & \\
\hline \multicolumn{5}{|l|}{ tOPV } \\
\hline Antipolio 1 & 2 & 2 & 100,0 & 48,00 \\
\hline Antipolio 2 & 6 & 4 & 66,7 & 24,00 \\
\hline Antipolio 3 & 28 & 16 & 57,1 & 9,75 \\
\hline mOPV1 & & & & \\
\hline Antipolio 1 & 19 & 19 & 100 & 69,47 \\
\hline
\end{tabular}

secara statistik $(p=0,04)$ (Tabel 4$)$. Peningkatan titer terjadi $100 \%$ pada subjek dengan kadar antibodi polio $<4$ baik kelompok mOPV1 maupun kelompok tOPV. Selanjutnya peningkatan akan menurun sesuai dengan tingginya kadar antibodi polio sebelumnya.

Pasca pemberian tOPV 43,7\% subjek mengalami peningkatan antibodi polio 1 dan pada kelompok mOPV1 yang mengalami peningkatan sebesar
$60,1 \%$, perbedaan ini bermakna secara statistik $(p=0,04)$.

- Imunogenesitas mukosa saluran cerna (Tabel 5)

- Keamanan vaksin tOPV dan mOPV (Tabel 6)

Setelah pemberian tOPV dalam 30 menit pertama, 1 subjek mengalami peningkatan suhu. Dalam kurun 
Kusnandi Rusmil: Perbandingan Vaksin Oral Polio 1 Monovalen dengan Trivalen Upaya Mengatasi KLB Polio Di Indonesia

Tabel 4. Jumlah subjek setelah imunisasi, kenaikan antibodi antipolio 1 pra ke pasca, dan Geometric Mean Titer (GMT) Antibodi Antipolio 1 berdasarkan vaksin tOPV dan mOPV1

\begin{tabular}{lcc}
\hline Titer antibodi antipolio-1 & $\begin{array}{c}\text { TOPV } \\
(\mathrm{n}=151)\end{array}$ & $\begin{array}{c}\mathrm{mOPV} 1 \\
(\mathrm{n}=148)\end{array}$ \\
\hline Kenaikan titer antibodi $\geq 4$ & $41(27,2)$ & $60(40,5)$ \\
Ya $(\mathrm{n}, \%)$ & $110(72,8)$ & $88(59,5)$ \\
Tidak (n, \%) & $85(56,3)$ & $59(39,9)$ \\
Kenaikan dari pra ke-pasca imunisasi & $66(43,7)$ & $89(60,1)$ \\
Tidak ada (n, \%) & & \\
Ada (n, \%) & $42,93(35,61-51,78)$ & $21,90(16,85-28,46)$ \\
GMT antibodi polio-1 & $52,30(42,22-64,78)$ & $54,84(44,28-67,90)$ \\
Antipolio-1 & $\mathrm{Z}_{\mathrm{w}}=1,488, p=0,137$ & $\mathrm{Z}_{\mathrm{w}}=5,45, p=<0,001$ \\
Pra & & \\
Pasca & & \\
Perbedaan pra-pasca & & \\
\hline Keterangan: $\mathrm{X}^{2}=5,49 ; p=0,014, \mathrm{X}^{2}=8,08 ; p=0,004$, & \\
$\mathrm{Z}_{\mathrm{m}-\mathrm{w}}=2,98$ (Uji Mann-Whitney) $\mathrm{Z}_{\mathrm{w}}=\mathrm{Uji}$ Wilcoxon &
\end{tabular}

waktu 30 menit sampai dengan 72 jam, 6 mengalami peningkatan suhu dan 4 mengalami muntah, 1 mengalami diare. Sedangkan dalam kurun waktu 72 jam sampai dengan 30 hari, 10 mengalami peningkatan suhu, 1 muntah, dan 20 lainnya mengalami reaksi lain seperti ISPA dan bisul. Dari 148 subjek yang mendapat mOPV1, dalam kurun waktu 30

Tabel 5. Perbandingan hasil isolasi antara vaksin tOPV dan mOPV1 pada hari ke-7 dan ke-21

\begin{tabular}{llll}
\hline \multirow{2}{*}{ Hasil Isolasi } & \multicolumn{2}{l}{ Vaksin } & Kemaknaan \\
\cline { 2 - 3 } HOPV & mOPV1 & \\
PISL & $6(12)$ & $19(38)$ & $\mathrm{X}^{2}=1,65$ \\
P2SL & $3(6)$ & - & $\mathrm{P}=0,198$ \\
P3SL & $4(8)$ & - & \\
NPEV & $2(4)$ & $4(8)$ & \\
Negatif & $35(70)$ & $27(54)$ & \\
Hari ke-21 (\%) & & & \\
PISL & $0(0)$ & $2(4)$ & $\mathrm{P}_{\mathrm{EF}}=0,168$ \\
P2SL & $3(6)$ & - & \\
P3SL & $4(8)$ & - & \\
NPEV & $0(0)$ & $3(6)$ & \\
Negatif & $43(86)$ & $45(90)$ & \\
\hline
\end{tabular}

Keterangan: PISL=Virus Polio -1 Sabin like, P2SL=. Virus Polio -2 Sabin like, P3SL= Virus Polio -3 Sabin like, NPEV= Nonpolio Enterovirus

Untuk kelompok mOPV1 : Perbandingan \% hasil isolasi hari ke-7 dan hari ke-21 (berdasarkan uji McNemar). Neg: $p=<0,001$; P1SL: $p=<0,001$; Npev: $p=1,0$

Untuk kelompok tOPV : Perbandingan \% hasil isolasi hari ke-7 dan hari ke-21 (berdasarkan uji McNemar). Neg: $p=0,077, \mathrm{NPev}: p=1,0, \mathrm{P} 1 \mathrm{SL}: p=0,289, \mathrm{P} 2+\mathrm{P} 3: p=0,125$ menit pertama 2 orang subjek mengalami keluhan masing-masing 1 orang demam dan satu orang muntah. Tidak terjadi reaksi KIPI yang serius selama penelitian.

\section{Pembahasan}

\section{Karakteristik subjek penelitian}

Apabila ditinjau umur di antara dua kelompok terdapat perbedaan yang bermakna antara subjek yang mendapat tOPV dan mOPV1 (Tabel1). Hal ini disebabkan perbedaan karakteristik puskesmas. Puskesmas di Bandung mempunyai fasilitas perawatan untuk melahirkan, sehingga semua bayi yang lahir pada saat PIN dimasukkan dalam subjek penelitian sehingga subjek penelitian di Bandung lebih muda dibandingkan subjek di Banjarbaru.

\section{Menilai kadar antibodi}

Sebelum imunisasi dengan tOPV terdapat $2(1,4 \%)$ subjek yang mempunyai kadar antibodi polio $1<4$ (di bawah ambang pencegahan) dan sebagian besar subjek berada pada kadar 16 sampai 128, setelah imunisasi masih terdapat 1 orang dengan kadar antibodi di bawah nilai pencegahan (Tabel 2). Untuk imunisasi mOPV1, persentase anak dengan antibodi antipolio 1 dengan kadar $<4,12,8 \%$ (19 subjek) dan setelah imunisasi menjadi 4 orang subjek (2,7\%).

Suatu studi melaporkan bahwa kadar antibodi 
Kusnandi Rusmil: Perbandingan Vaksin Oral Polio 1 Monovalen dengan Trivalen Upaya Mengatasi KLB Polio Di Indonesia

Tabel 6. Kejadian ikutan pasca-imunisasi mOPV1 dan tOPV

\begin{tabular}{|c|c|c|c|}
\hline \multirow{2}{*}{ Kejadian ikutan pascaimunisasi } & \multicolumn{2}{|c|}{ Vaksin (\%) } & \multirow{2}{*}{ Kemaknaan } \\
\hline & tOPV $(\mathrm{n}=151)$ & mOPV1 $(\mathrm{n}=148)$ & \\
\hline $\begin{array}{l}\text { Setelah vaksinasi } 1 \text { dosis } \\
\text { a. Gejala yang langsung timbul dalam } \\
30 \text { menit setelah imunisasi }\end{array}$ & $1(0,7)$ & $2(1,3)$ & $P_{E F}=0,620$ \\
\hline $\begin{array}{l}\text { b. Gejala yang langsung timbul dalam } \\
30 \text { menit sampai } 72 \text { jam setelah } \\
\text { imunisasi }\end{array}$ & $11(7,3)$ & $22(14,9)$ & $\begin{array}{l}X^{2}=4,37 \\
p=0,036\end{array}$ \\
\hline $\begin{array}{l}\text { c. Setiap gejala yang timbul setelah } \\
72 \text { jam sampai } 30 \text { hari setelah } \\
\text { imunisasi }\end{array}$ & $31(20,5)$ & $9(6,1)$ & $\begin{array}{c}\mathrm{X}^{2}=13,47 \\
p<0,001\end{array}$ \\
\hline $\begin{array}{l}\text { Gabungan keseluruhan dari } 30 \text { menit } \\
\text { pertama sampai dengan } 30 \text { hari sete- } \\
\text { lah imunisasi }\end{array}$ & $38(25,2)$ & $27(18,2)$ & $\begin{array}{l}\mathrm{X}^{2}=1,78 \\
p=0,190\end{array}$ \\
\hline
\end{tabular}

antipolio tripel positif paling tinggi terdapat pada kelompok yang mengikuti PIN dan imunisasi rutin $78 \%$, kemudian yang hanya mengikuti imunisasi rutin $76 \%$, yang hanya mengikuti PIN $65 \%$ dan yang terendah adalah yang tidak mengikuti sama sekali program imunisasi $14,3 \% .^{12}$

Beberapa penelitian melaporkan bahwa serokonversi yang tertinggi disebabkan oleh virus polio 2 , diikuti virus polio 1 dan yang terendah oleh virus polio 3. Hal ini disebabkan adanya perbedaan, berat molekul dan sekuen nukleotida pada virus polio. Berat molekul tertinggi terdapat pada polio 2, diikuti polio 1 dan kemudian virus polio $3 .{ }^{13}$ Penelitian tahun 1987 terhadap 50 bayi baru lahir sampai dengan umur 2 bulan, (ibu maupun anak belum pernah diimunisasi), dilaporkan 47 (94\%) ibu tripel positif dan 33 anak (70\%) tripel positif (mengandung antibodi ketiga tipe polio), tidak ditemukan satu orang bayi pun yang seronegatif (tripel negatif). ${ }^{14}$ Selanjutnya penelitian terhadap 60 bayi yang lahir di RS Hasan Sadikin Bandung pada tahun 1988, sebelum diberikan tOPV ditemukan semua subjek telah seroprotektif untuk ketiga serotipe polio. Setelah pemberian 3-4 kali tOPV, pada umur 3 hari, 2 bulan, 3 bulan, 4 bulan, maka pada umur 5 bulan didapatkan seropositif $90 \%$ untuk antipolio $1,100 \%$ untuk antipolio 2 dan antipolio 3 serta terjadi peningkatan titer yang bermakna untuk semua serotipe. ${ }^{15}$ Penelitian di Cina ${ }^{7}$ setelah pemberian 4 kali tOPV pada bayi sejak berumur tiga hari juga memberikan hasil yang hampir sama, seropositif 99\% untuk antibodi antipolio 1, $100 \%$ antipolio 2, dan $99 \%$ antipolio $3 .{ }^{16}$ Penelitian di Yogyakarta tahun 1994, dari 54 bayi seronegatif sebelum diberikan imunisasi terjadi serokonversi terhadap masing-masing tipe poliovirus, $98 \%$ untuk antibodi antipolio 1, 98\% antipolio 2, dan 94\% antipolio 3. Di Irian Jaya tahun 1996-1997, setelah pemberian tOPV saat dua kali PIN, 97\% tripel positif dan 100\% sesudah PIN kedua. ${ }^{17,18}$

Pada pra imunisasi dari 19 subjek dengan seronegatif setelah 30 hari pasca imunisasi dengan satu dosis mOPV1 semua subjek menjadi seropositif (seroconvertion rate 100\%). Penelitian di 13 negara di Amerika Utara dan Selatan, Eropa, Afrika, dan Asia dengan jumlah subjek berkisar 18-154 anak, rata-rata serokonversi antibodi antipolio 1 berkisar antara 53$100 \%$ (median 95\%). ${ }^{16}$

Jumlah subjek yang mengalami peningkatan titer $\geq 4$ kali pada kelompok tOPV lebih sedikit dibandingkan dengan mOPV1. Namun peningkatan titer terjadi $100 \%$ pada subjek dengan kadar antibodi polio $<4$ baik kelompok mOPV1 maupun kelompok tOPV. Selanjutnya peningkatan akan menurun sesuai dengan tingginya kadar antibodi polio sebelumnya.

Salah satu keuntungan digunakan vaksin monovalen dibanding trivalen (tOPV) bahwa dengan dosis tunggal vaksin monovalen ini akan memperlihatkan imunogenisitas yang tinggi pada resipien di negara non-tropis (median sero-konversinya 90\% untuk virus polio 1 dan virus polio 2 , dan $85 \%$ untuk virus polio 3), sedangkan di negara tropis umumnya lebih rendah (81\% untuk virus polio 1, 89\% polio 2 , dan $72 \%$ 3) dan imunogenesitas ini setara jika dibandingkan dengan tingkat serokonversi di negara- 
negara berkembang setelah pemberian dua dosis tOPV.9 Sebuah penelitian menunjukkan bahwa sekitar $80 \%$ anak di negara tropis akan mempunyai kekebalan terhadap virus polio 1 setelah dosis pertama mOPV1 dibandingkan dengan 40\% anak setelah pemberian tOPV di negara tropis. Pemberian imunisasi dengan tOPV menyebabkan polio Sabin tipe 2 bersama enterovirus patogen lain di dalam saluran cerna akan mengintervensi respons imun polio 1 dan polio 3 pada saat awal pembentukan kekebalan dalam saluran cerna sehingga kekebalan saluran cerna terhadap polio 1 dan 3 menjadi berkurang, pada vaksin monovalen hal ini tidak terjadi. ${ }^{18}$

\section{Kekebalan mukosa usus}

Penelitian kami menggambarkan bahwa setelah imunisasi OPV akan menimbulkan kekebalan di mukosa usus terhadap virus polio. Tidak ditemukan perbedaan yang bermakna antara kelompok tOPV dan mOPV terhadap ekskresi virus polio pada feses pada hari ke-7 dan ke-21. Akan tetapi bila dibandingkan berkurangnya ekskresi virus polio dari feses pada hari ke-7 dan ke-21 setelah pemberian mOPV1 dan tOPV maka kelompok mOPV1 berkurang secara bermakna. Ghendon dan Sanakoyeva melaporkan bahwa setelah pemberian mOPV1 dengan tiga dosis berturut-turut, 37\% subjek mengekskresikan virus polio dan lama mengekskresi kurang lebih 4-5 hari. ${ }^{16}$

Imunisasi OPV akan memberikan hasil yang efektif, sebab vaksin OPV di samping merangsang pembentukan antibodi dalam sirkulasi yang mencegah penyebaran penyakit polio ke susunan syaraf pusat. Dilain pihak sIgA yang terbentuk akan membatasi atau mencegah seeding virus polio sehingga dapat mencegah infeksi polio berikutnya. Antibodi sekretori di nasofaring dan intestinal terjadi dalam satu sampai dengan tiga minggu setelah imunisasi. ${ }^{19}$ Penelitian yang dilakukan pada musin dingin di Houston pada bayi berumur 0-6 bulan setelah pemberian imunisasi tOPV ditemukan ekskresi virus polio 1, 2, dan 3 di dalam feses dalam minggu pertama masing-masing sebesar $72 \%, 88 \%$, dan $75 \% .{ }^{20}$ Ekskresi virus polio dapat terjadi walaupun subjek telah mempunyai kadar anti polio yang protektif dalam sirkulasi. Adanya ekskresi virus polio dalam feses mengambarkan bahwa masih terjadi multiplikasi virus di dinding saluran cerna, artinya saluran cerna yang bersangkutan belum kebal secara total. ${ }^{19}$

\section{Keamanan vaksin tOPV dan mOPV1}

Kejadian ikutan pascaimunisasi (KIPI) adalah suatu kejadian sakit yang terjadi setelah menerima imunisasi yang diduga disebabkan oleh imunisasi. ${ }^{11}$ Makin sering terjadinya reaksi vaksin yang tidak diinginkan maka diasumsikan makin tidak aman vaksin tersebut. Tidak ada perbedaan yang bermakna di antara kelompok tOPV dan mOPV1 berdasarkan KIPI yang dilaporkan. Tidak ditemukan kejadian ikutan pasca imunisasi yang serius selama penelitian. Dari hasil penelitian disimpulkan bahwa pemberian 1 dosis mOPV1 dibandingkan dengan pemberian satu dari tOPV pada PIN ke-5 saat KLB tahun 2005 memberikan respons imun yang lebih baik serta keamanan yang sama sehingga mempercepat pemutusan rantai penularan virus polio-1. Hal ini dibuktikan dengan adanya keunggulan dalam peningkatan kekebalan yang ditinjau dari serokonversi, peningkatan titer $\geq 4$ kali, titer geomatric rata-rata, dan kekebalan mukosa usus.

\section{Ucapan terima kasih}

Peneliti mengucapkan terima kasih kepada PT. Bio Farma yang telah mendanai penelitian ini dan izin dari Sub-Direktorat Imunisasi Departemen Kesehatan Republik Indonesia, Dinas Kesehatan Kodya Bandung, Puskesmas Garuda, Puskesmas Padasuka, Puskesmas Kiaracondong, Dinas Kesehatan Kabupaten Banjarbaru Kalimantan Selatan, Puskesmas Banjarbaru, Puskesmas Sei Besar dan Puskesmas Cempaka, sejawat dr. Novilia SB, dr. Eddy Fadlyana, SpA(K).,MKes, dr. Meita Dhamayanti, SpA(K), dr. Erman Boediono, MM., dr. H. Kartini, MM., dr. Diah Widyastuti, dr. Tandrihastuti, dr. Dina Pugar, dr. Awa Purwanti, dr. Ati Semiati, Drs. Edi Sampana, M.Kes., dr. Jane Soepardi, MPH.,DSc., Dr. dr. Julitasari Soendoro, MSc.,PH yang telah membantu penelitian dan penulisan naskah.

\section{Daftar pustaka}

1. Departemen Kesehatan Republik Indonesia. Laporan SubPIN, Jakarta: Depkes RI; 2006.

2. Simoes EAF. Poliomyelitis. Dalam: Behrman RE, Kliegman RM, Jenson HB, penyunting. Nelson textbook of 
pediatrics. Edisi ke-18. Philadelphia: Saunders; 2007. h.1344-50.

3. Plotkin SA, Vidor E. Poliovirus vaccine-inactivated. Dalam: Plotkin SA, Orenstein WA, penyunting. Vaccines. Edisi ke-4. Philadelphia: WB Saunders; 2004.h.62550.

4. Roitt I, Brostoff J, Male D. Immunology. Edisi ke-6. Toronto: Mosby; 2001.

5. Garna K. Imunologi dasar. Edisi ke-7. Jakarta: FKUI; 2006.

6. Johnson PA, Bhattacharyya M. Statistics. Principles and methods. Edisi ke-3. New York: John Wiley and Sons; 1996.

7. Budiarto E. Biostatistika untuk kedokteran dan kesehatan masyarakat. Jakarta: Penerbit Buku Kedokteran EGC; 2001.

8. Furesz J. The clinical effectiveness and safety of monovalent oral poliovirus vaccines for use in emergency outbreak control in the post eradication era. Geneva: WHO; 2002.

9. Cáceres VM, Sutter RW. Sabin monovalent oral polio vaccines: review of past experiences and their potential use after polio eradication; review of monovalent polio vaccines: Clin Infect Dis 2001; 33:53-541.

10. Bio Farma National Polio Laboratory, ITD result, version 7 Oktober 2005. [Brosur]

11. Satari HI. Kejadian ikutan pasca imumisasi. Dalam: Ranuh IGM, Soeyitno H, Hadinegoro SRS, Kartasasmita C, penyunting. Buku pedoman imunisasi di Indonesia. Edisi ke-2. Jakarta: Satgas imunisasi IDAI; 2005.h.222-31.

12. Hasan AS, Malik A, Shukla I, Malik MA. Antibody levels against polioviruses in children following polio immunization program. Ind Pediatr 2004;41:1040-4.

13. Vincent.R. Picornaviridae. The viruses and their replication. Dalam: David M Knipe, Peter M Howley penyunting. Field of Virology. Edisi ke-4 Vol 1. Leppincott Williams and Wilkins; 2002.h.695-775

14. Firman A. Penilaian status kekebalan terhadap polio pada anak balita penduduk kotamadya Bandung pengunjung unit rawat jalan RS.Hasan Sadikin ditinjau dari gambaran serologis. Tesis. Bandung: Universitas Padjadjaran; 1989

15. Hindun NS. Gambaran titer antibodi polio pada bayi yang diberi imunisasi dasar polio secara oral mulai umur 3 hari dan umur 2 bulan. Tesis. Bandung: Universitas Padjadjaran; 1989.

16. World Health Organization. Modul 6: poliomyelitis. Immunological basis for immunization series. Geneva: WHO; 1996.

17. Gendrowahyuono. Bio Farma oral polio vaccine trial in Yogyakarta. Communicable diseases research center national institute of health research and development. Medika. 1994.

18. Gendrowahyuhono. Polio serological research on children after national immunization day I and II in remote areas. Communicable diseases research center national institute of health research and development. Medika. 1997.

19. Sabin A. Effect of oral polio vaccine in newborn children. Pediatrics 1963:641-50.

20. Plotkin S, Plotkin P. Short history of vaccination. Dalam: Plotkin SA, Orenstein WA, penyunting. Vaccines. Edisi ke-4. Philadelphia: WB Saunders; 2004.h.1-16. 